\title{
Adoption Level of Farmers Regarding Organic Farming Practices in Madhya Pradesh state of India
}

\author{
Ankit Malviya ${ }^{1}$, Jitendra $\operatorname{Verma}^{1 *}$ and Anil Dawar ${ }^{2}$ \\ ${ }^{1}$ Department of Agriculture Extension Education, ${ }^{2}$ Department of Soil Science \& Agriculture \\ Chemistry, Dr. B.R. Ambedkar University of Social Sciences, Dr. Ambedkar Nagar (Mhow), \\ M.P., India \\ *Corresponding author
}

\section{A B S T R A C T}

\section{Keywords \\ Village Panchayat, Farmers, Organic Farming Practices, Adoption Level}

Article Info

Accepted:

22 June 2020 Available Online: 10 July 2020
The Indian economy as one of fastest growing economies among the developing countries of world and Agriculture of backbone of Indian economy India, agriculture contributes of about sixteen percent of total GDP of contributed as $17.5 \%$ to country Gross Values Added of the year of 2018. Given the importance as agriculture sector and of percent of total exports also of major source as livelihoods, particularly in the rural area, as 55 per cent of people living of India in Madhya Pradesh farming of major source of livelihood and self employment of near about of $80 \%$ of the population living on rural area after the green revolution as launched on India, substantial of increasing in the production of food grains as achieved use of improved crop varieties and of higher level of input and fertilizers of plant protection chemicals of realized as increasing in production of achieved at cost soil health of Organic farming as defined as a production system, as avoids or largely excludes of synthetically compounded fertilizers with pesticides, of plant growth regulators and livestock feed additive and of maximum extent feasible, organic farming systems rely of crop rotations, crops residues, animal manures with of legumes, green manures, off-farm organic wastes, of mineral bearing rocks and aspects as biological pest control to maintain a soil productivity with of soil, to supply plant nutrients and of control insects, weeds. The Madhya Pradesh Governments of started advocating organic farming practices on major crops as area of observed of farmers as adopting of recommended of organic farming practices as study of designed to explore the adoption level of farmers regarding organic farming practices in Madhya Pradesh state of India. In view of the objectives of the study 100 organic farmers were be selected through proportionate random sampling method from the selected village panchayat. Majority of the organic farmers 56.00 per cent had medium adoption level regarding organic farming practices.

\section{Introduction}

India of second most populous country in world with of increasing population, of cultivable land resource as shrinking day to day of to meet the food, fodder with needs of growing population, the productivity of agricultural soil and soil of health needs to be improved. Green Revolution in the post independence as path to developing countries 
of self-sufficiency on food sustaining agricultural of production against the finite of natural resource demands shifted from the resource degrading chemical agriculture of resource protective biological and organic agriculture of Green revolution technologies a greater of synthetic agrochemicals use of fertilizers and pesticides, as no side-effects of the modern agricultural of total chemicals and of machines raise serious questions as overall benefits of new technology and Chemical fertilizers 2 and pesticides pollute as air and water of agriculture chemicals, including hormones and of antibiotics leave residue on food of cancer or genetic damage. The soil of energy resources depleted of Instead of recycling of wastes back soil fertilizer, of polluted of water and of use non-renewable energy resources to produce as artificial fertilizer and of future may be forced to make the radical adjustments of agricultural practices. Despite the global awareness of environmental degradation and of climatic change as could resulting of continuous practice as inorganic farming and a poses on sustainable agricultural of production so that the adoption of nutrient-responsive, as high yielding varieties of crops, greater exploitation as irrigation potentials of boosted as production output in most cases and continuous use of high energy inputs indiscriminately now leads to the decline in production of productivity of various crop as deterioration of soil health with environments. The Adoption of organic farming as reported that the positive correlation of number of cattle maintained of farmers, in the state of large farmers of more cattle with more resources of organic manure are facilitates of more area under organic farming and FYM as common source of organic manure used of the organic farming, followed by vermicompost and NADEP as compost of farmers as using bio-gas slurry, of green manure and cow horn manure with Poultry manure, of neem cake and bio-fertilizers of rhizobium, azospirillum, with phosphate solubilzing bacteria etc and of supplements used of under of off-farm organic sources. Thereof, keeping the above facts in mind, the present study is entitled as "Adoption level of farmers regarding organic farming practices."

\section{Materials and Methods}

The study was entirely concerned with organic practices conducted by farmers. A cumulative list of village panchayat was prepared on the basis of farmers who practice the organic farming. The village panchayat having maximum number of organic farmers were selected from prepared list and five village panchayat were selected from selected block through random sampling method. The organic farmers are main source of information. In view of the objectives of study 100 organic farmers will be selected through proportionate random sampling method from the selected village panchayat. A well-structured and pretested interview schedule was used of data collection through personal interview method. The following statistic was used of Study on Adoption level of farmers regarding organic farming practices. The data was analyzed by using percentage, standard deviation and correlation coefficient.

\section{Results and Discussion}

The overall adoption level of farmers in different practices of organic farming practices in the study area is depicted in Table 1. The results indicated that adoption level of the recommended practices in four major practices of organic farming viz., In-situ method for nutrient management, Use of predigested manure, Bio-fertilizers and Cultural Methods were found to be $60.00,62.00,62.00$ and 59.00 per cent, respectively. Higher adoption level was observed in Use of predigested manure and Bio-fertilizers while 
lower adoption level was in Cultural Methods. The adoption level of Cultural Methods was found to be lower as compared to other organic farming practices. The overall adoption level of organic farming practices in the study area was found to be only 61.00 Per cent indicating the need to educate the dairy farmers on different aspects of organic farming practices in general and practices of organic farming practices in particular. The present finding is in close conformity with the findings of Pandey et al., (2011) and Singh and Varshaney (2010).

Table.1 Adoption level of farmers regarding organic farming practices

\begin{tabular}{|c|c|c|c|c|c|}
\hline \multirow[t]{2}{*}{ S.N. } & \multirow[t]{2}{*}{ Organic Farming Practices } & \multicolumn{3}{|c|}{ Adoption Level of Farmers } & \multirow[t]{2}{*}{ Percentage } \\
\hline & & Low & Medium & High & \\
\hline 1. & In-situ method for nutrient management & 30 & 60 & 10 & 60.00 \\
\hline a. & The Green manures & 33 & 57 & 10 & 59.00 \\
\hline b. & The Crop residues & 11 & 76 & 13 & 68.00 \\
\hline c. & The Poultry manure & 18 & 70 & 12 & 65.00 \\
\hline d. & The Urban and rural wastes & 36 & 59 & 5 & 56.00 \\
\hline e. & The Recycling the weed biomass & 35 & 54 & 11 & 58.00 \\
\hline f. & The Recycling the agro based industrial wastes & 32 & 59 & 9 & 59.00 \\
\hline g. & The Fish wastes & 36 & 54 & 10 & 58.00 \\
\hline h. & The Use of oil industry products & 34 & 55 & 11 & 59.00 \\
\hline i. & The Sewage farming & 35 & 56 & 9 & 58.00 \\
\hline 2. & Use for pre-digested manure & 25 & 64 & 11 & 62.00 \\
\hline a. & The Farm yard manure & 31 & 57 & 12 & 60.00 \\
\hline b. & The Composting & 16 & 73 & 11 & 65.00 \\
\hline c. & Other livestock wastes & 14 & 70 & 16 & 68.00 \\
\hline d. & Biomass conversion of unconventional methods & 39 & 56 & 5 & 55.00 \\
\hline 3. & Bio-fertilizers & 32 & 51 & 17 & 62.00 \\
\hline a. & The N-fixing agents & 41 & 42 & 17 & 58.00 \\
\hline b. & The N-containing vegetation & 30 & 51 & 19 & 63.00 \\
\hline c. & P-Solubilizing microbes & 34 & 55 & 11 & 59.00 \\
\hline d. & The Vermin-culture & 18 & 61 & 21 & 68.00 \\
\hline e. & The N-fixing crops and trees & 37 & 46 & 17 & 60.00 \\
\hline 4. & Cultural Methods & 37 & 49 & 14 & 59.00 \\
\hline a. & $\begin{array}{l}\text { The Crop rotation with pulses for N- The } \\
\text { Fixation }\end{array}$ & 42 & 39 & 19 & 59.00 \\
\hline b. & $\begin{array}{l}\text { The Intercropping with pulses for N- The } \\
\text { Fixation }\end{array}$ & 47 & 35 & 18 & 56.00 \\
\hline c. & The Minimum tillage for nutrient conservation & 27 & 61 & 12 & 62.00 \\
\hline d. & The Agro-forestry methods i.e. alley cropping & 32 & 56 & 12 & 60.00 \\
\hline e. & The Strip cropping and vegetative/live bunds & 39 & 50 & 11 & 57.00 \\
\hline \multirow[t]{2}{*}{ f. } & The Mulching cover crops. & 35 & 53 & 12 & 59.00 \\
\hline & Over all organic farming practices & 31 & 56 & 13 & 61.00 \\
\hline
\end{tabular}


Table.2 Distribution of farmers according to their adoption level regarding organic farming practices

\begin{tabular}{|c|l|c|c|}
\hline S.N. & \multirow{2}{*}{ Items } & \multicolumn{2}{|c|}{ Organic Farmers $(\mathbf{N}=\mathbf{2 0 0})$} \\
\hline & & Frequency & Percentage \\
\hline 1. & Low & 31 & 31 \\
\hline 2. & Medium & 56 & 56 \\
\hline 3. & High & 13 & 13 \\
\hline & Total & $\mathbf{1 0 0}$ & $\mathbf{1 0 0}$ \\
\hline
\end{tabular}

Table.3 Relationship of independent variables with adoption level of farmers regarding organic farming practice

\begin{tabular}{|c|l|c|}
\hline S.N. & \multicolumn{1}{|c|}{ Independent variables } & Correlation coefficient value 'r' \\
\hline 1. & X1 Age of farmers & -0.034 N.S. \\
\hline 2. & X2 Education status of farmers & $0.4350^{* *}$ \\
\hline 3. & X3 Farming experience of farmers & $0.2540^{*}$ \\
\hline 4. & X4 Farm size of farmers & $0.2510^{*}$ \\
\hline 5. & X5 Total annual income of farmers & $0.2500^{*}$ \\
\hline 6. & X6 Livestock possession of farmers & $0.2710^{*}$ \\
\hline 7. & X7 Information sources utilization & $0.3790^{*}$ \\
\hline 8. & X8 Extension contact of farmers & $0.4500^{* *}$ \\
\hline 9. & X9 Mass media exposure of farmers & $0.4460 * *$ \\
\hline 10. & X10 Market orientation of farmers & $0.5270^{* *}$ \\
\hline 11. & X11 Knowledge Level of farmers & 0.9700 \\
\hline Significant at 0.05 level of probability; $* *$ Significant at 0.01 level of probability with 98 d.f. NS= Non-Significant
\end{tabular}

Fig.1 Distribution of farmers according to their adoption level regarding organic farming practices

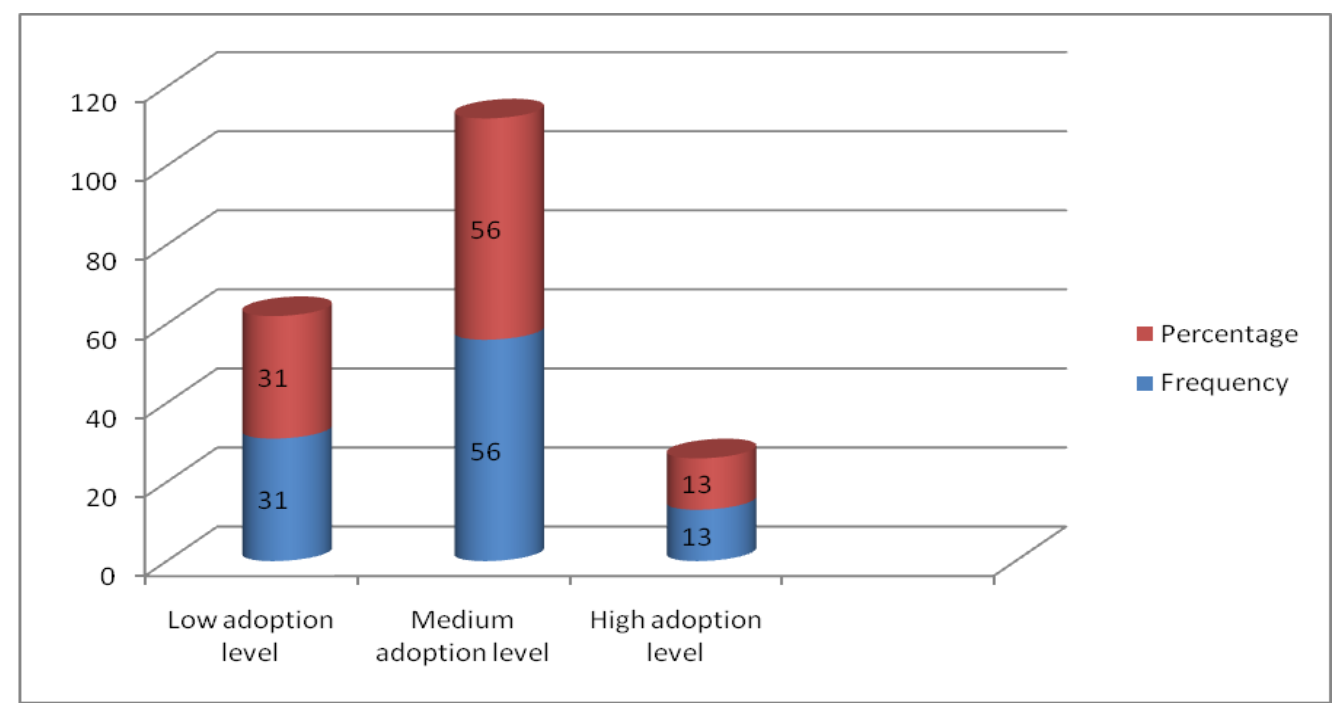


The data presented in Table $2 \&$ Fig 1 indicates that nearly 56.00 per cent of the organic farmers had medium adoption level regarding organic farming practices followed by low 31.00 per cent and high 13.00 per cent, respectively. The results of this study are in same line of findings repeated by Bana et al., (2014) and Singhal and Vatta (2017). Thus, the result clearly indicates that in the study area, showed medium adoption level regarding organic farming practices because the farmers gained knowledge through different type of training conducted by KVK and other agriculture departments regarding organic farming practices.

The data presented in the Table 3 indicates that, education status of farmers, Farming experience of farmers. Farm size of farmers, Total annual income of farmers, Livestock possession of farmers, Information sources utilization, Extension contact of farmers, Mass media exposure of farmers, Market orientation of farmers, Knowledge Level of farmers found to be significantly correlated with adoption level of farmers regarding organic farming practices. Only the Age of farmers found to be non-significantly correlated with adoption level of farmers regarding organic farming practices. The results of this study are in same line of findings repeated by Krishna et al., (2017).

Thus, it can be concluded that in the study area, the adoption level of farmers regarding organic farming practices was medium. This could be due to the exposure of the farmers to knowledge through different type of training conducted by $\mathrm{KVK}$ and other agriculture departments about organic farming $\mathrm{f}$ practices.

\section{References}

Bana SS, Sharma NK, Badhala BS and Ghaswa R. 2014. Adoption of beneficiary farmers as compared to nonbeneficiary farmers about recommended Bajra production technology. Ind. J. Extn. Educ. \& R.D. 22: 207-210.

Krishna B., Chakravarthi K and Nityanand, Babu R., Naveen and Sreekar. 2017. Adoption of Improved Dairy Husbandry Practices and Its Relationship With The Socio-Economic Characteristics of Dairy Farmers In Kadapa District Of Andhra Pradesh. International Journal of Science, Environment and Technology, Vol. 6, No 4, 2017, 2353 2357.

Pandey SK, Gautam US, Rai DP and Mustafa M. 2011. Knowledge and adoption of gram production technology. Indian Journal of Extension Education. 47 (3\&4): 37-39.

Singh P.K. and varshaney JG. 2010. Adoption level and constraints in rice production technology. Indian Research Journal of Extension Education. 10 (1).

Singhal S and Vatta L. 2017. Impact of Krishi Vigyan Kendra on Adoption of Improved Agricultural Production Practices. International Journal of Environment Science and Technology, ISSN 2278-3687 (O) Vol. 6, No 2, 993 1000 .

\section{How to cite this article:}

Ankit Malviya, Jitendra Verma and Anil Dawar. 2020. Adoption Level of Farmers Regarding Organic Farming Practices in Madhya Pradesh state of India. Int.J.Curr.Microbiol.App.Sci. 9(07): 3551-3555. doi: https://doi.org/10.20546/ijcmas.2020.907.415 